\title{
THE COMPOSITION OF STRIKE ACTIVITY IN THE CONSTRUCTION INDUSTRY
}

\author{
DAVID B. LIPSKY and HENRY S. FARBER
}

$\mathrm{T}$ HE construction industry may be the most strike-prone industry in the American economy: since the end of World War II there have been nearly 25,000 construction strikes, accounting for approximately 20 percent of the nation's strike activity. In the turbulent I960s about 22 percent of both the number of strikes and the number of mandays lost because of strikes were attributable to construction stoppages. Yet over the same period the construction work force constituted only about 5 percent of the nonagricultural labor force. ${ }^{1}$

This study shows that strikes in construction have, by most measures, increased during the years since 1949 , a period during which strike activity tended to decline in American industry as a whole. The authors demonstrate that this increase has resulted not from an increase in the number of wage disputes but from a growing number of jurisdictional strikes and the increasing severity of economic and unionorganizing strikes. They also show that the number of strikes in construction does not vary significantly with the unemployment rate in that industry nor with the presence of wage controls, but both of those factors have a significant impact on the composition of strike activity in construction.

David B. Lipsky is Associate Professor in the New York State School of Industrial and Labor Relations, Connell University. Henry S. Farber is a graduate student in the Department of Economics at Princeton University. They would like to thank John Raudabaugh and Robert Searle for their research assistance on this project. This paper was submitted and accepted before Professor Lipsky assumed the position of editor-EDrTor

1Major sources for data on construction strikes include the following: U.S. Department
Construction workers are on strike more frequently and lose more working time than workers in any other industry. Record levels of strike activity were recorded in 1969 when there were nearly 1,000 strikes and 20 million mandays lost because of work stoppages. While workers in the rest of the economy lost about one-quarter of one percent of working time because of strikes, construction workers lost five times that amount. It can be argued that this militancy on the part of construction unions helped bring about the large wage settlements in the industry in 1969 and 1970 and, ultimately, wage conrtols in 1971 .

In an address before the Convention of the AFL-CIO Building and Construction Trades Department in 1971, John

of Labor, Bureau of Labor Statistics, Work Stoppages in Contract Construction, 1946-66, BLS Report No. 346 (Washington, D.C.: G.P.O., 1968); E. A. Puglisi and A. Stolzberg, "Work Stoppages, 1961-66: Construction and Other Industries," reprinted in Construction Labor Report, No. 657 (April 24, 1968), pp. B-2 to B-9; U.S. Department of Labor, Bureau of Labor Statistics, Handbook of Labor Statistics 1972, Bulletin 1735 (Washington, D.C.: G.P.O., 1972), pp. 345-56; U.S. Department of Labor, Burcau of Labor Statistics, Analysis of Work Stoppages 1972, Bulletin 1813 (Washington, D.C.: G.P.O., 1974). In addition, unpublished data were obtained from the Bureau of Labor Statistics for the years after 1967. For an excellent survey of labor relations in construction, see Daniel Quinn Mills, Industrial Relations and Manpower in Construction (Cambridge, Mass.: M.I.T. Press, 1972). Mills discusses the industry's strike problem on pp. $48-49$ and $69-70$. 
Dunlop, then chairman of the Construction Industry Stabilization Committee (CISC), noted that "one out of three collective bargaining agreements in 1970 resulted in a strike, whereas in American industry generally, roughly one out of 20 agreements result in a work stoppage. That record did not do credit to any of us with interests or attachments to this industry." Noting that the industry's strike record represented "a failure of collective bargaining," Dunlop told the convention delegates, "Whether you like it then, or not, it seems the situation was somewhat out of control."'2

In this paper we address ourselves to the problem of strike activity in the construction industry. Most previous strike studies have been limited to analyses aggregated across industries. Aggregation, however, may conceal more than it reveals. Strike propensities are clearly different across industries and over time, so that estimates of strike determinants based on aggregated data may be biased or unstable.

Furthermore, it is not true that all or even the great majority of strikes occur over wages, an assumption implicit in most previous studies. In fact, strikes also occur over job security issues and other working conditions, as a result of union organizing drives, and because of jurisdictional disputes between rival unions. Such noneconomic strikes are particularly common in the construction industry. For example, over the postwar period jurisdictional disputes accounted for about one-third of all strikes in the industry, and in recent years there have actually been more strikes on jurisdictional questions than because of unresolved wage disputes. Jurisdictional stoppages, however, cannot always be

2 Construction Labor Report, No. 843 (November 17, 1971), p. C-1. attributed to a breakdown in labormanagement negotiations. Thus, failure to account for the actual sources of strike activity can lead to misleading estimates of strike propensities.

It is also necessary to recognize that no single measure can serve as an adequate index of strike activity. Some of the most important studies in this area have examined only the number of strikes. In this study we examine not only strike frequency, but also other relevant indices.

\section{Strikes in Construction}

The Chart traces the postwar record of strike activity in the construction industry and in all industries. The allindustry figures show a general downward trend from the Korean War period through the early 1960s. (The large number of mandays idle in 1959 is largely the result of a single, 116-day steel strike.) Throughout most of the 1960 s, however, total strike activity increased quite markedly; from 1960 to 1970 the number of mandays idle, for example, increased by nearly 250 percent.

For the construction industry the eye perceives no downward trend at all. Al-

Chart. Number of Strikes and Mandays Idle-All Industries and Construction Industry-1948-72.

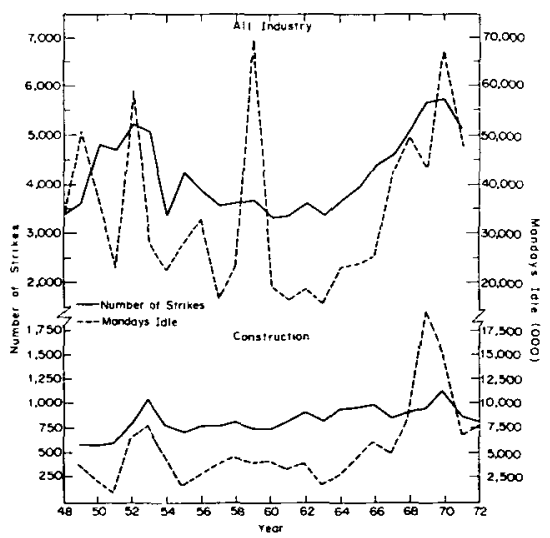


though there is clearly year-to-year variation, the drift in both the number of strikes and mandays idle appears to be steadily upward for most of the postwar period. In fact, from 1949 to 1970 the number of construction strikes increased by 85 percent and the number of mandays idle by 450 percent.

The Chart presents some evidence of a restraining effect on strike levels during the three postwar periods when an active incomes policy was pursued (1951$52,1962-66$, and 1971-72). This is particularly true for measures of time lost. After the creation of the CISC in 1971, Dunlop continually emphasized that wage stabilization was only part of the committee's tasks and that dispute settlement was an equally important function. ${ }^{3}$ Subsequently he credited CISC with significantly reducing the strike level in construction in 1971 and 1972.4 The number of strikes dropped, in fact, from 1,137 in 1970 to 751 in 1971 and 701 in 1972, the lowest levels recorded since 1955. Mandays idle also dropped by more than 50 percent in 1971 , after the creation of CISC.

The Nixon controls program, however, also appears to have had a similar impact on total strike activity in 1971 and 1972 , and yet mandays idle for all strikes dropped by about 30 percent in 1971, even though Phase I did not go into effect until August-a fact suggesting that other restraining forces may have been at work in the economy as a whole and perhaps also in construction. On the

3See, for example, Construction Labor Report, No. 858 (March 8, 1972), p. A-18 and No. 904 (January 3I, 1973), p. A-12.

${ }^{4}$ Construction Labor Report, No. 904 (January 31, 1973), p. A-11 to A-12. This article recounts Dunlop's testimony before the Senate Banking Committee on the Administration's proposal for a one-year extension of the Economic Stabilization Act. other hand, it appears the Korean War controls and the Kennedy wage guidelines also had an impact on construction strike activity. Time lost because of construction strikes reached postwar lows in 1951 and 1963, years when there was heavy government pressure to restrain wage increases. The apparent effect of the Kennedy guidelines on construction strike activity is odd, however, because it is generally agreed that this voluntary wage control program had little impact on other facets of construction collective bargaining. ${ }^{5}$ Obviously this question of the effects of controls requires more systematic analysis, which we will provide later in this paper.

For purposes of analysis, we divide construction strike activity into five categories according to the major cause of the stoppage:

Total. This category contains stoppages occurring for any reason and is the sum of the other four plus a residual category that cannot otherwise be classified. ${ }^{6}$

Economic. This category includes any stoppage that stems principally from a dispute over wage changes, wage adjustments, hours of work, and supplementary benefits.

Working conditions. This category includes disputes arising over job security issues, contract administration, and other noneconomic contractual matters. It includes both strikes over the negotiation of new contract terms and strikes during the term of the contract; unfortunately, the Bureau of Labor Statistics (BLS) does not subdivide the strike data to permit us to distinguish grievance strikes.

\footnotetext{
iSee, for example, John Sheahan, The WagePrice Guideposts (Washington, D.C.: The Brookings Institution, 1967), pp. 38-40.

${ }^{6}$ Less than one percent of measured strike activity is included in the residual category for all strike measures and in all years.
} 
Union organizing and security. This category includes strikes arising from efforts by unions to organize unorganized workers, obtain a representation election from the National Labor Relations Board (NLRB), gain recognition from the employer, and win various forms of union security.

Jurisdictional. This category includes all stoppages arising from interunion and intraunion rivalries. If two unions compete over the organization of a particular group of workers and a strike results, it is classified in this category. A more typical jurisdictional dispute, however, involves competition over jobs rather than workers. In the construction industry, it is common to have two unions disagree on the proper assignment of work. If a contractor assigns jobs to members of Union A, Union B may strike to force a reassignment of the work.

Clearly, as the BLS notes, "The issues in dispute in most strikes are many and varied, and do not always lend themselves readily to immediate and exact classification."' Over the years, however, the BLS has developed considerable expertise in the proper classification of strikes by issue, and the categories employed here are broad enough so that classification errors are minimized.

The classification of strikes by cause does not include consideration of the legal status of the strike." For example, almost all jurisdictional strikes are violations of Section $8(\mathrm{~b})(4)(\mathrm{D})$ of the TaftHartley Act. Also, it is well known that secondary boycotts, an unfair labor prac-

iU.S. Department of Labor, Bureau of Labor Statistics, BLS Handbook of Methods, Bulletin 1711 (Washington, D.C.: G.PO., 1971), p. 162. Further information on the methods used by the BLS to classify strikes is available in this source. tice under Section $8(b)(4)(B)$ of TaftHartley, are a common occurrence in the construction industry. ${ }^{9}$ Most of the union-organizing strikes probably violate Section $8(b)(4)(C)$ or $8(b)(7)$ of TaftHartley. In addition, many strikes over "working conditions" are strikes in contravention of no-strike provisions in collective agreements and are subject to both contract remedies and damage suits. ${ }^{10}$ There is no way of estimating the proportion of construction strike activity that may be unlawful, but an index of the magnitude is provided by the number of court injunctions issued against strikes by construction workers. In most years, more injunctions are issued against strikes in construction than in any other industry in the private sector. ${ }^{11}$

\section{Measures of Strike Activity}

Our earlier discussion focused on two measures of strike activity: number of strikes and mandays idle. Additional measures are required to understand the

s"All stoppages, whether or not authorized by the union, legal or illegal, are counted." Ibid., p. 159.

often secondary strikes are the result of common situs picketing. Such picketing was declared an unlair labor practice in NLRI3 v. Demer Building Trades Council, 341 U.S. 675. Between 1958 and 1968 the NLRB heard 82 cases involving the issue of secondary strikes; by far the largest number, 46, involved construction unions. See Paul A. Brinker, "Secondary Strikes and Picketing," Labor Law Journal, Vol. 23, No. 11 (November 1972), pp. 681-82. Brinker and raylor found that construction unions were involved in 63 percent of 548 sccomdary boycott cases heard by the NLRB between 1958 and 1970. See Paul A. Brinker and Benjamin J. Taylor, "Secondary Boycott Analysis by Industry," Labor Law Journal, Vol. 24, No. 10 (October 1973), pp. 671-73.

10 Boys Market, Inc., v. Retail Clerks Union, Local 1770,398 U.S. 235 (1970).

isee, for example, U.S. Department of Labor, Analysis of Work Stoppages, 1971 (Washington, D.C.: G.P.O., 1973), p. 59. 
full dimensions of strike activity. Some researchers have devoted considerable energy to delineating the "shape" of industrial conflict on the grounds that there must be a relationship between shape and effectiveness. Hicks, for example, argued that long strikes must result in employer victories: "To fight out to the bitter end can only mean going back upon the employers' terms". ${ }^{12}$ Knowles, in his classic examination of British strike experience between 1911 and 1938, also concluded that unions were victorious when strikes were numerous, large, and short, and that employers tended to win when strikes were few, small, and long. ${ }^{13}$ Studies by Shorter and Tilly and by Britt and Galle view unionization as the means of mobilizing worker protest and making it more effective. The rise of unionization over the past century has led to more frequent, broader, but shorter strikes, and, inferentially, to greater strike effectiveness for workers. ${ }^{14}$

Following Britt and Galle, we use these symbols to denote measures of strike activity:

$$
\begin{array}{ll}
W S & =\text { number of work stoppages } \\
M D I= & \text { number of mandays idle } \\
W I & = \\
& \text { number of workers in- } \\
& \text { volved in work stoppages }
\end{array}
$$

12John Richard Hicks, The Theory of Wages (New York: St. Martin's Press, 1968), p. 145.

13K.G.J.C. Knowles, Strikes: $A$ Study in Industrial Conflict (Oxford: Basil Blackwell, 1954), pp. 240-59.

14Edward Shorter and Charles Tilly, "The Shape of Strikes in France, 1930-1960," Comparative studies in Society and History, Vol. 13, No. 1 (January 1971), pp. 60-86; David Britt and Omer R. Galle, "Industrial Conflict and Unionization," American Sociological Review, Vol. 37, No. 1 (February 1972), pp. 46-57; David Britt and Omer R. Galle, "Structural Antecedents of the Shape of Strikes: A Comparative Analysis," American Sociological Review, Vol. 39, No. 5 (October 1974), pp. 642-51. and we add the following symbols:

$$
\begin{aligned}
M D W= & \text { number of mandays worked } \\
& \text { in the industry } \\
W K R S= & \text { number of workers em- } \\
& \text { ployed in the industry. }
\end{aligned}
$$

Thus we can define the following components of strike activity:

\begin{tabular}{ll} 
Component & Measure \\
\cline { 2 - 2 } Frequency & $W S$ \\
Relative frequency & $W S / M D W$, \\
& $W S / W K R S$ \\
Volume & $M D I$ \\
Relative volume or & $M D I / M D W$, \\
severity & $M D I / W K R S$ \\
Breadth or size & $W I / W S$ \\
Intensity or duration & $M D I / W I$ \\
Scale & $M D I / W S$
\end{tabular}

In the regression models that follow we will use five of the above measures: frequency $(W S)$, relative frequency (WS/ $M D W)$, volume $(M D I)$, relative volume $(M D I / M D W)$, and scale $(M D I / W S)$. We are prohibited from using separate measures of size and duration because data on workers involved $(W I)$ by the major causes of construction strikes are available only for years through 1967. Note, however, that scale is the product of size and duration. That is,

$$
\frac{M D I}{W S}=\frac{W I}{W S} \cdot \frac{M D I}{W I}
$$

Thus, scale is an adequate proxy for duration if size is relatively constant. In the construction industry, data for all stoppages show that the average strike for the period 1946-67 involved 385 workers; yearly means over this period generally fell within 150 of the mean for the entire period. ${ }^{15}$ The yearly variation in mean duration, however, was propor-

${ }^{15}$ The one exception was 1952 when the mean was 849 . The range for other years was from 248 (1963) to 552 (1953). 
tionally much greater, ranging from 5 to 25 days. Therefore, variation in the scale of construction strikes results principally from variation in their duration.

It is worth noting that the average size of construction strikes is consider. ably smaller than the size of strikes for all industries. In Table 1 it can be seen that the average construction stoppage involved 352 workers in 1967, while the all-industry average was 624 workers.

Two hypotheses are suggested to explain the smaller size of construction strikes. First, it may be the result of the decentralized nature of collective bargaining in the industry. Since negotiations in the industry are usually carried on between local craft organizations and contractor associations, one might not expect strikes of considerable breadth. Second, it may be caused by the high incidence of construction strikes over noneconomic issues. Grievance strikes, organizing strikes, and jurisdictional disputes, after all, usually involve smaller numbers of workers than strikes over wages and other money items.

The evidence suggests that the second hypothesis is probably correct. The data in Table 1, giving size and duration sta- tistics for 1967 (the last year for which complete information is available), show that the average strike over economic issues involved almost as many workers in construction as in "all industries" and was of even longer duration in construction. The small size of construction strikes is therefore principally attributable to the high incidence and smaller size of noneconomic stoppages in the industry, not to the structure of bargaining on wage issues.

Although the variance in the size of economic stoppages in construction is relatively small, there are a few "statistical outlyers," indicating that the large economic strike is not an unknown occurrence in the industry. For example, of 18 strikes involving 10,000 or more workers in 1972, 10 occurred in the construction industry; in fact, the largest stoppage in any industry in that year involved 70,000 carpenters and plasterers who struck the Builders Association of Chicago. ${ }^{16}$ This was during a period when CISC applied all the pressure it could muster to reduce conflict in the industry.

16U.S. Department of Labor, Analysis of Work Sloppages, 1972, pp. 12-13.

Table 1. The Average Size and Duration of Work Stoppages in All Industries and in Construction, 1967.

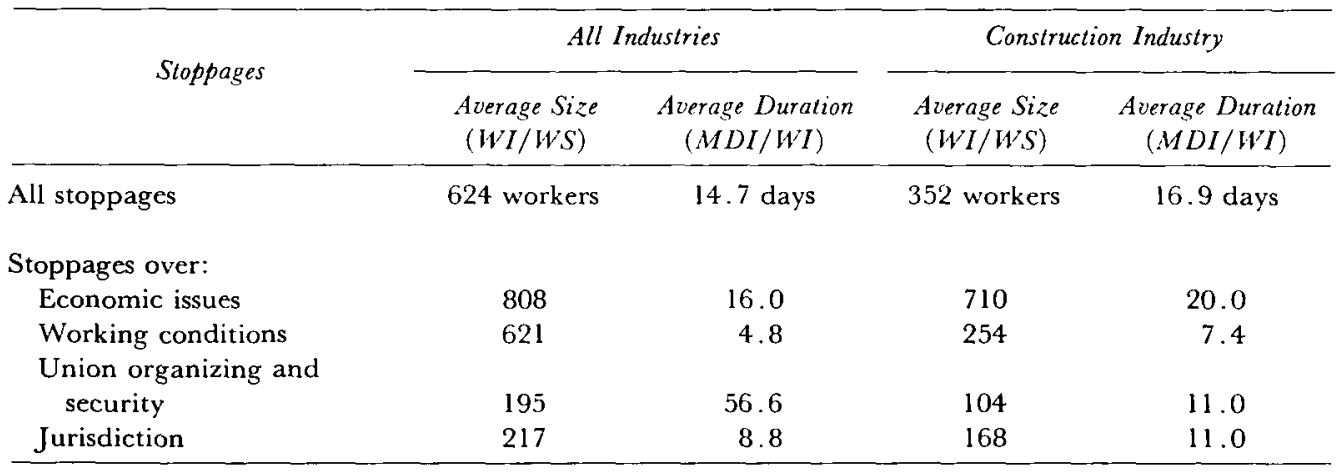

Source: All-industries figures are derived from U.S. Department of Labor, Bureau of Labor Statistics, Handbook of Labor Statistics 1972 (Washington, D.C.: G.P.O., 1972), Table 157, p. 341. 


\section{A Regression Model}

How can variations in construction strike activity over the postwar period be explained? The literature led us to examine five hypotheses concerning the movement of construction strike levels. Our preliminary explorations caused us to concentrate on a linear regression model combining three of the hypotheses. The variables included in our final model follow:

Trend. Many researchers have discovered evidence of a declining level of strike activity over time. Arthur Ross and Paul Hartman found this to be markedly true in northern European countries and somewhat true of the United States. They referred to this as "the withering away of the strike."17 Ross and Hartman attributed the declining propensity to strike in North America to several factors, particularly "the abatement of rivalry within the union movement." 15 They also credited changes in employer attitudes, a growing centralization of bargaining, and a greater involvement of unions in political action as contributing to the decline in strike activity. ${ }^{19}$

Ashenfelter and Pierce found that for the period 1945-63 four of five tested measures of strike activity (WS, $M D I$, $M D I / M D W, W I$ ) showed a significant negative trend. ( $M D I / W I$ had an insignificant trend coefficient.) $)^{20}$ These authors considered the decline in industrial conflict to be consistent with a sociological theory presented by Dubin: "First,

17Arthur M. Ross and Paul T. Hartman, Changing Pattern of Industrial Conflict (New York: John Wiley and Sons, 1960), pp. 42-61.

1sIbid., p. 164.

19lbid., pp. 161-171.

soOrley Ashenfelter and William S. Pierce, "Industrial Conflict: The Power of PredictionComment," Industrial and Labor Relations Re. view, Vol. 20, No. 1 (October 1966), pp. 92-95. as time passes during which groups of people practice specified forms of behavior, institutions develop which tend to stabilize that behavior. Second, as such institutionalization occurs, individuals and groups acquire an interest in perpetuating the stabilized systems of behavior."21 The well-known paper that Ashenfelter later coauthored with Johnson analyzed the number of strikes beginning in each quarter from 1952 to 1967 and showed, through use of a model that included several other variables, that the volume of aggregate strike activity exhibited a significant downward trend over that period. Ashenfelter and Johnson accounted for this decline by pointing to the changing composition of strike activity, particularly the decline in strikes resulting from union-organizing campaigns and over unsettled grievances. ${ }^{22}$

Our earlier discussion of the strike record in construction revealed an apparent upward trend throughout most of the postwar period, at least for the measures WS and $M D I$. Certainly the strike does not" appear to be withering away in the construction industry. It is therefore of some interest to discover if all measures of construction strikes show an upward trend and if the composition of strike activity affects the overall trend.

Unemployment. One of the clearest results of industrial relations research is that strikes follow the business cycle, or, in other words, that strikes and unemployment are inversely correlated. This

21 Ibid., p. 92. The theory is originally presented in Robert Dubin, "Industrial Conflict: The Power of Prediction," Industrial and Labor Relations Review, Vol. 18, No. 3 (April 1965), pp. 352-63.

2oOrley Ashenfelter and George Johnson, "Bargaining Theory, Trade Unions, and Industrial Strike Activity," American Economic Review, Vol. 59, No. 1 (March 1969), pp. 35-49. 
finding has been repeatedly confirmed for the United States, Canada, and Great Britain. ${ }^{23}$ The theoretical reasons for the inverse relation do not need to be repeated here. The same arguments should have relevance for the relation between economic strikes and unemployment at the disaggregated, industry level. But whether noneconomic stoppages should have the same relation to unemployment is problematical and, as far as we know, untested.

Wage Controls. The casual evidence cited in Strikes in Construction (above) indicated that the three postwar periods of wage and price controls seemed to have a restraining effect on strike levels. As Dunlop made clear, it was the conscious aim of CISC to reduce strike levels in construction, and Phases I and II of general controls seemed to have an impact on strike activity throughout industry.

Mitchell, in his analysis of the impact of Phase II, found some evidence that strike levels were decreased. He pointed out, however, that wage controls dramatically increased the proportion of one-year contracts negotiated in the construction industry in 1971. In 1972, therefore, an unusual number of construction contracts expired and the opportunity to strike increased in that

23:For the United States, see Ashenfelter and Johnson, "Bargaining Theory," and the references cited therein. See also Jack W. Skeels, "Measures of U.S. Strike Activity," Industrial and Labor Relations Review, Vol, 24, No. 4 (July 1971), pp. 515-25. For Canada, see John Vanderkamp, "Economic Activity and Strikes in Canada," Industrial Relations, Vol. 9, No. 2 (February 1970), pp. 215-30. (But note that Vanderkamp finds a weaker, though still significant, relation in Canada compared to the United States.) For Great Britain, see John $\mathbf{H}$. Pencavel, "An Investigation into Industrial Strike Activity in Britain," Economica, New Series, Vol. 37, No. 147 (August 1970), pp. 239-56. industry after the imposition of controls. That suggests, in turn, that although the low level of strike activity in the rest of industry during Phase II may be attributed to the light bargaining calendar, ${ }^{24}$ this factor cannot be adduced as a reason for the decline in construction strikes in 1972.

Ashenfelter and Johnson argued that the Kennedy-Johnson wage guidelines lowered the number of strikes by lowering the wage rate acceptable to the union at the point of contract expiration. ${ }^{25}$ In terms of Hicks's bargaining model, this is equivalent to a leftward shift of the union's "resistance curve." 26 All other things equal, such a shift should lower both the value of the wage settlement and the expected length of a strike.

Pencavel pointed out, however, that if "a policy of wage restraint is coupled with attempts to moderate product price increases, the employer will be more intransigent in the wage bargain in the knowledge that his ability to pass on wage increases in the form of higher prices is more limited." "'; Again, in Hicksian terms, this is equivalent to a rightward shift of the employer's "concession curve." Such a shift would put further downward pressure on wage settlements, but would increase the expected length of a strike.

In the construction industry it is generally agreed that wage controls have been more effective than price controls. Therefore, we would expect periods of wage controls to be associated with de-

¿4 Daniel J. B. Mitchell, "Phase II Wage Controls," Industrial and Labor Relations Review, Vol. 27, No. 3 (April 1974), pp. 373-75.

25Ashenfelter and Johnson, "Bargaining Theory," p. 47.

"6Hicks, The Theory of Wages, pp. 136-58.

27Pencavel, "An Investigation into Industrial Strike Activity in Britain," p. 248. 
creases in economic stoppages in the industry.

We tested two additional hypotheses concerning the movement of strike levels. A key variable in the Ashenfelter and Johnson model is a moving average of previous changes in real wages $(\Delta R)$. Using quarterly data, Ashenfelter and Johnson estimated a polynomial lag distribution in $\Delta R$; specifically, changes in real wages over the previous eight quarters were estimated to have an impact on current strike levels. The relation between strikes and $\Delta R$ was found to be clearly negative, suggesting that the cumulative experience of strong advances in real wages serves to dampen current strike activity. ${ }^{28}$

Unfortunately, we have only annual observations and therefore could not test a quarterly lag distribution on $\Delta R$. The best we could do was to test the relation between the change in real wages in construction over the previous two years and current strike activity. Although we tried several formulations of this variable, with all measures and categories of construction strikes, the coefficients were predominantly insignificant. One might expect lagged wage changes to have a particular effect in the equations pertaining to economic strikes. All coefficients for $\Delta R$, however, were insignifcant in this subgroup of equations. One could speculate on why the results for construction were so markedly different from the Ashenfelter and Johnson results, but we prefer to be cautious since we lacked the data to duplicate their test precisely. Consequently, the $\Delta R$ variable was dropped from our final tests.

The final variable we tested was suggested in part by Ashenfelter and John-

\footnotetext{
asAshenfelter and Johnson, "Bargaining
}

son and in part by Philip Ross. Ashenfelter and Johnson tested the possibility that the passage of the Landrum-Griffin Act in 1959 had a positive impact on the amount of strike activity. The use of a dummy variable confirmed the hypothesis. After 1959 there seems to have been a step-increase in aggregate strike levels. ${ }^{-9}$ According to Ross, the LandrumGriffin Act "led to a fundamental shift in the form of the [construction] industry's hiring practices." Section $8(\mathrm{f})$ permitted contracts that set up union referrals based on seniority, residence, and experience. "Under the prodding of the international unions who distributed to their locals detailed model referral systems embodying Section 8(f)'s priorities, thousands of locals formally adopted the hiring hall."30 Employer opposition, however, was intense and "many bitter strikes took place."'31

Accordingly, we tested for the effect of the Landrum-Griffin Act on construction strike activity. This variable, however, did not have a significant impact, and it was dropped in the final tests. Part of the problem in testing the variable was its high collinearity with the wage control dummy. Tests showed that wage controls had considerably more impact on strikes than the LandrumGriffin Act.

\section{Empirical Results}

Table 2 presents linear regression results using three independent variables (trend, unemployment rate in construction, and a wage control dummy) and twenty-five dependent variables representing our five measures of strike activ-

\footnotetext{
2!Ibid., p. 47.

30Philip Ross, "Origin of the Hiring Hall in Construction," Industrial Relations, Vol. 11, No. 3 (October 1972), p. 377. 31 Ibid.
} 
ity in each of five categories of strikes, as previously discussed.32 Annual observations for the time period $1949-71$ are used. The wage control dummy takes a value of 1 in the years 1951, 1952, 1962 through 1966, and 1971. It would have been desirable to test each period of wage controls separately, but the small number of observations precluded that approach.

In order to correct for the possibility of autocorrelation in the regressions, all equations were estimated using an autoregressive scheme devised by Cochrane and Orcutt. ${ }^{33}$ As shown in the last column of Table 2, the tests indicated that the ordinary least squares (OLS) estimates could be accepted for sixteen of the twenty-five equations. A first-order scheme was used in six equations and a second-order scheme in three. After the application of the Cochrane-Orcutt technique, the Durbin-Watson statistics shown in Table 2 indicate an absence

\footnotetext{
$3:$ Ideally one would want to add controls in our regression tests for year-to-year variations in bargaining opportunities. This could be accomplished if complete data were available on yearly contract expirations in the industry. Unfortunately, the BLS only provides information on expirations of contracts covering 1,000 or more workers. It is our impression that the one-year contract was the norm in construction for a much longer period than in other industries, which suggests that our regression estimates are not seriously biased. If multiyear contracts have grown significantly over time, the most serious impact would be on the trend coefficients, which would be biased in a downward direction. The other independent variables would be affected only if they correlated with the omitted variable. With the exception of Mitchell's finding concerning the effect of Phase II on contract duration, noted above, we have no evidence indicating that such correlations are significant.

33D. Cochrane and G. H. Orcutt, "Application of Least Squares Regressions to Relationships Containing Auto-correlated Error Terms," Journal of the American Statistical Association, Vol. 44, No. 245 (March 1949), pp. 32-61.
}

of positive autocorrelation in eighteen equations and a value in the inconclusive range in the other seven cases.

Trend. In the category "all stoppages," there is a significant positive trend for four of the five measures. ${ }^{34}$ Strikes in the industry have not only tended to increase in frequency, they have apparently become more serious in volume and scale ( $M D I$ and $M D I / W S$ ). Only relative frequency $(W S / M D W)$ shows no significant trend. The high level of significance of the absolute measures $W S$ and $M D I$, and the absence of a trend for $W S / M D W$, indicate that the upward trend is possibly associated with a generally growing economy and the increasing size of the labor force in the industry.

Techniques of dealing with autocorrelation are discussed in J. Johnston, Econometric Methods, 2d ed. (New York: McGraw-Hill, 1972), pp. 26265. For the purposes of this study a simple first order autocorrelation scheme of the form

$$
\varepsilon_{t}=p \varepsilon_{t-1}+u_{t}
$$

was assumed and the Cochrane-Orcutt iterative procedure was used to provide an estimate of $p$ $(\hat{\mathbf{p}})$. If $\hat{\mathrm{p}}$ was significantly different from zero at the 5 percent level and second order autocorrelation could be ruled out on the basis of the Durbin-Watson statistic, then the first order Cochrane-Orcutt estimates were used. If $\hat{\mathrm{p}}$ was not significantly different from zero, then OLS estimates were used.

Where $\hat{\mathrm{p}}$ was significantly different from zero at the 5 percent level and second order autocorrelation of the form

$$
\varepsilon_{t}=p_{1} \varepsilon_{t-1}+p_{2} \varepsilon_{t-2}+u_{t}
$$

could not be ruled out by the Durbin-Watson statistic, a second order Cochrane-Orcutt procedure was used to provide estimates of $p_{1}$ and $\mathrm{p}_{2}\left(\hat{\mathrm{p}}_{1}\right.$ and $\left.\hat{\mathrm{p}}_{2}\right)$. If $\hat{\mathrm{p}}_{1}$ and $\hat{\mathrm{p}}_{2}$ were both significantly different from zero at the 5 percent level, then the second order Cochrane-Orcutt estimates were used. If not, the first order Cochrane-Orcutt estimates were used. A flow chart of this procedure is available from the authors.

${ }_{34}$ Pencavel ("An Investigation into Industrial Strike Activity in Britain," p. 252.) also found a significant positive trend for construction strikes in Britain. 
Table 2. Regression Results: Strike Activity in the Construction Industry. ${ }^{a}$

\begin{tabular}{|c|c|c|c|c|c|c|c|}
\hline Measure & Trend & $\begin{array}{l}\text { Unemployment Rate } \\
\text { in Construction }\end{array}$ & $\begin{array}{l}\text { Wage Control } \\
\text { Dummy }\end{array}$ & Constant & $\mathbf{R}^{2}$ & D. W. & $\begin{array}{l}\text { Method of } \\
\text { Estimation }\end{array}$ \\
\hline \multicolumn{8}{|c|}{ All Sloppages } \\
\hline$W S$ & $\begin{array}{l}11.624 \\
(3.420)^{* * *}\end{array}$ & $\begin{array}{r}-9.0287 \\
(1.211)\end{array}$ & $\begin{array}{r}-20.263 \\
(.4355)\end{array}$ & $\begin{array}{l}825.03 \\
\quad(8.497)^{* * *}\end{array}$ & .4557 & 1.7254 & OLS \\
\hline$W S / M D W$ & $\begin{array}{c}-.000282 \\
(.5842)\end{array}$ & $\begin{array}{c}-.000119 \\
(.1124)\end{array}$ & $\begin{array}{r}-.00257 \\
(.3893)\end{array}$ & $\begin{array}{c}.11992 \\
(8.705)^{* * *}\end{array}$ & .0305 & 1.8835 & OLS \\
\hline$M D I$ & $\begin{array}{l}252.997 \\
(3.256)^{* * *}\end{array}$ & $\begin{array}{l}-384.13 \\
(2.253)^{* *}\end{array}$ & $\begin{array}{l}-2297.9 \\
(2.159)^{* *}\end{array}$ & $\begin{array}{l}7439.8 \\
\quad(3.350)^{* * *}\end{array}$ & .5273 & 1.5719 & OLS \\
\hline$M D I / M D W$ & $\begin{array}{c}.0211 \\
(2.030)^{*}\end{array}$ & $\begin{array}{l}-.0437 \\
(1.919)^{*}\end{array}$ & $\begin{array}{l}-.2744 \\
(1.929)^{*}\end{array}$ & $\begin{array}{l}1.0287 \\
(3.465)^{* * *}\end{array}$ & .3775 & 1.5383 & OLS \\
\hline$M D I / W S$ & $\begin{array}{l}.2111 \\
(2.913)^{* * *}\end{array}$ & $\begin{array}{l}-.3403 \\
(2.140)^{* *}\end{array}$ & $\begin{array}{c}-2.1172 \\
(-2.133)^{* *} \\
\end{array}$ & $\begin{array}{l}8.0659 \\
(3.894)^{* * *}\end{array}$ & .4878 & 1.4042 & OLS \\
\hline \multicolumn{8}{|c|}{ Economic Sloppages } \\
\hline$W S$ & $\begin{array}{r}-2.253 \\
\quad(.8975)\end{array}$ & $\begin{array}{r}-9.117 \\
(1.655)\end{array}$ & $\begin{array}{l}-79.235 \\
(2.305)^{* *}\end{array}$ & $\begin{array}{l}493.685 \\
\quad(6.881)^{* * * *}\end{array}$ & .3012 & 1.8099 & OLS \\
\hline$W S / M D W$ & $\begin{array}{l}-.00119 \\
(3.072)^{* * *}\end{array}$ & $\begin{array}{c}-.000824 \\
(.9730)\end{array}$ & $\begin{array}{l}-.01078 \\
(2.040)^{*}\end{array}$ & $\begin{array}{c}.07282 \\
(6.604)^{* * *}\end{array}$ & .4577 & 1.7884 & OLS \\
\hline$M D I$ & $\begin{array}{l}206.446 \\
(2.770)^{* *}\end{array}$ & $\begin{array}{c}-398.155 \\
(2.435)^{* *}\end{array}$ & $\begin{array}{l}-2543.70 \\
(2.491)^{* *}\end{array}$ & $\begin{array}{l}7167.01 \\
\quad(3.364)^{* * *}\end{array}$ & .5112 & 1.5635 & OLS \\
\hline$M D I / M D W$ & $\begin{array}{l}.01667 \\
(1.680)\end{array}$ & $\begin{array}{l}-.0466 \\
(2.139)^{* *}\end{array}$ & $\begin{array}{l}-.3050 \\
(2.244)^{* *}\end{array}$ & $\begin{array}{c}.9838 \\
(3.469)^{* * *}\end{array}$ & .3868 & 1.5641 & OLS \\
\hline$M D I / W S$ & $\begin{array}{c}.6098 \\
(4.570)^{* * *}\end{array}$ & $\begin{array}{l}-.8123 \\
(2.776)^{* *}\end{array}$ & $\begin{array}{l}-4.268 \\
(2.337)^{* *}\end{array}$ & $\begin{array}{l}15.330 \\
(4.022)^{* * *}\end{array}$ & .6596 & 1.6452 & OLS \\
\hline \multicolumn{8}{|c|}{ Stoppages over Working Conditions } \\
\hline$W S$ & $\begin{array}{r}-1.8817 \\
(1.288)\end{array}$ & $\begin{array}{l}.15392 \\
(.0880)\end{array}$ & $\begin{array}{l}19.844 \\
(2.160)^{* *}\end{array}$ & $\begin{array}{l}109.376 \\
(4.012)^{* * *}\end{array}$ & .5940 & 1.7703 & $\begin{array}{l}\text { First Order } \\
\text { Cochrane-Orcutt }\end{array}$ \\
\hline$W S / M D W$ & $\begin{array}{l}-.00040 \\
(2.010)^{*}\end{array}$ & $\begin{array}{l}.000123 \\
(.4894)\end{array}$ & $\begin{array}{c}.00297 \\
(2.227)^{* *}\end{array}$ & $\begin{array}{c}.0152 \\
(3.990)^{* * *}\end{array}$ & .5451 & 1.7722 & $\begin{array}{l}\text { First Order } \\
\text { Cochrane-Orcutt }\end{array}$ \\
\hline$M D I$ & $\begin{array}{l}.9991 \\
(.2870)\end{array}$ & $\begin{aligned}-14.691 \\
\\
(1.923)^{*}\end{aligned}$ & $\begin{array}{l}75.723 \\
(1.588)\end{array}$ & $\begin{array}{l}277.155 \\
(2.785)^{* *}\end{array}$ & .3031 & 1.8950 & OLS \\
\hline
\end{tabular}




\begin{tabular}{|c|c|c|c|c|c|c|c|}
\hline$M D I / M D W$ & $\begin{array}{c}-.000217 \\
(.5028) \\
.01505 \\
(.4280) \\
\end{array}$ & $\begin{array}{l}-.00188 \\
(1.980)^{*} \\
-.1505 \\
(1.943)^{*}\end{array}$ & $\begin{array}{c}.0101 \\
(1.712) \\
.3886 \\
(.8037) \\
\end{array}$ & $\begin{array}{l}.0397 \\
(3.230)^{* * *} \\
3.021 \\
(2.995)^{* * *}\end{array}$ & 2933 & 1.9265 & OLS \\
\hline \multicolumn{8}{|c|}{ Union Organizing and Security Stoppages } \\
\hline$w s$ & $\begin{aligned}-1.143 \\
(.9011)\end{aligned}$ & $\begin{array}{l}1.4068 \\
(.2227)\end{array}$ & $\begin{array}{l}.1246 \\
(.0127)\end{array}$ & $\begin{array}{l}101.929 \\
\quad(3.907)^{* * *}\end{array}$ & .3742 & 2.1275 & $\begin{array}{l}\text { First Order } \\
\text { Cochrane-Orcutt }\end{array}$ \\
\hline$W S / M D W$ & $\begin{array}{l}-.000315 \\
(3.872)^{* * *}\end{array}$ & $\begin{array}{r}.000509 \\
(2.855)^{* *}\end{array}$ & $\begin{array}{l}.00123 \\
(1.104)\end{array}$ & $\begin{array}{c}.0119 \\
(5.140)^{* * *}\end{array}$ & .6068 & 1.7221 & OLS \\
\hline$M D I$ & $\begin{array}{l}40.679 \\
(3.203)^{* * *}\end{array}$ & $\begin{array}{l}55.366 \\
(2.010)^{*}\end{array}$ & $\begin{array}{l}194.082 \\
(1.085)\end{array}$ & $\begin{array}{r}-553.39 \\
(1.559)\end{array}$ & .6813 & 2.3632 & $\begin{array}{l}\text { Second Order } \\
\text { Cochrane-Orcutt }\end{array}$ \\
\hline$M D I / M D W$ & $\begin{array}{c}.00484 \\
(2.674)^{* *}\end{array}$ & $\begin{array}{r}.00784 \\
(2.030)^{*}\end{array}$ & $\begin{array}{l}.02174 \\
(.8802)\end{array}$ & $\begin{array}{l}-.0712 \\
(1.427)\end{array}$ & .6611 & 2.2832 & $\begin{array}{l}\text { Second Order } \\
\text { Cochrane-Orcutt }\end{array}$ \\
\hline$M D I / W S$ & $\begin{array}{c}.4383 \\
(3.114)^{* * *} \\
\end{array}$ & $\begin{array}{r}.3254 \\
(1.118) \\
\end{array}$ & $\begin{array}{l}1.746 \\
(.9488) \\
\end{array}$ & $\begin{array}{l}3.518 \\
(.9263) \\
\end{array}$ & .7050 & 2.0735 & $\begin{array}{l}\text { Second Order } \\
\text { Cochranc-Orcutt }\end{array}$ \\
\hline \multicolumn{8}{|c|}{ Jurisdictional Stoppages } \\
\hline$\cdot W S$ & $\begin{array}{l}9.736 \\
(4.390)^{* * *}\end{array}$ & $\begin{array}{c}-3.950 \\
(1.158)\end{array}$ & $\begin{array}{r}-6.836 \\
(.3670)\end{array}$ & $\begin{array}{l}215.98 \\
(4.535)^{* * *}\end{array}$ & .8395 & 1.5534 & $\begin{array}{l}\text { First Order } \\
\quad \text { Cochrane-Orcutt }\end{array}$ \\
\hline$W S / M D W$ & $\begin{array}{c}.000828 \\
(3.239)^{* * *}\end{array}$ & $\begin{array}{r}-.00007 \\
(.1668)\end{array}$ & $\begin{array}{r}-.00022 \\
(.0955)\end{array}$ & $\begin{array}{c}.02858 \\
(5.007)^{* * *}\end{array}$ & .7161 & 1.6214 & $\begin{array}{l}\text { First Order } \\
\text { Cochrane-Orcutt }\end{array}$ \\
\hline$M D I$ & $\begin{array}{l}-7.581 \\
(2.258)^{* *}\end{array}$ & $\begin{array}{l}-44.05 \\
\quad(5.830)^{* * *}\end{array}$ & $\begin{array}{r}-16.850 \\
(.3412)\end{array}$ & $\begin{array}{l}802.33 \\
(8.290)^{* * *}\end{array}$ & .5316 & 2.2422 & $\begin{array}{l}\text { First Order } \\
\text { Cochrane-Orcutt }\end{array}$ \\
\hline$M D I / M D W$ & $\begin{array}{l}-.00161 \\
(2.398)^{* *}\end{array}$ & $\begin{array}{l}-.00546 \\
(3.711)^{* * *}\end{array}$ & $\begin{array}{r}-.00153 \\
(.1672)\end{array}$ & $\begin{array}{l}.1091 \\
(5.692)^{* * *}\end{array}$ & .4638 & 2.6740 & OLS \\
\hline$M D I / W S$ & $\begin{array}{l}-.0852 \\
(4.240)^{* * *}\end{array}$ & $\begin{array}{l}-.1610 \\
(3.650)^{* * *}\end{array}$ & $\begin{array}{c}-.0121 \\
(.0440) \\
\end{array}$ & $\begin{array}{c}3.624 \\
(6.360)^{* * *} \\
\end{array}$ & .5766 & 2.5662 & OLS \\
\hline \multicolumn{8}{|c|}{ 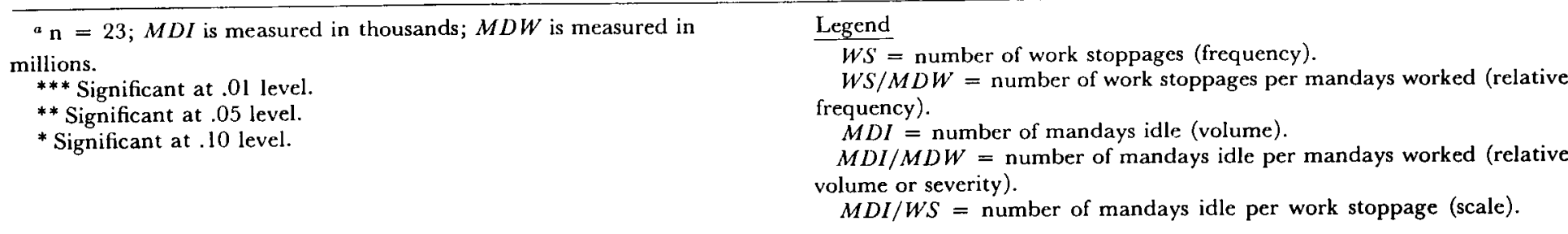 } \\
\hline
\end{tabular}


A growing construction labor force, however, is not a sufficient explanation for the positive trend coefficients, since the trend variable has not produced the same result in studies of strikes in other industries. Obviously, many of the reasons previous researchers have offered for the general decline in the propensity to strike do not apply to construction: union rivalry has not appreciably abated in the industry, bargaining has shown no tendency-until recently-to become more centralized, and the growing open or "merit" shop movement signifies no greater acceptance by many construction employers of the institution of collective bargaining.

In addition, the peaceful procedures used for settling noneconomic disputes in other industries have been less successful in construction. Because of the nature of the industry, the building trades must engage in continual organizing campaigns. The NLRB has always had a difficult time using the certification-election device in the industry, and unions have often preferred to rely on their "persuasive powers" to gain recognition from contractors. Also, as noted, jurisdictional disputes are endemic in the industry, and the parties' efforts to solve these disputes peacefully through the National Joint Board grew increasingly difficult through the period studied and, indeed, virtually collapsed after the Associated General Contractors withdrew from the plan in 1969.35 Finally, although grievance arbitration is provided in over 90 percent of the contracts in the industry, it is not ordinarily accompanied by an absolute ban on strikes during the contract term. In a survey of 769 construction contracts in effect in

35 Construction Labor Report, No. 843 (November 17,1971$)$, p. C-3.
$1972-73$, the BLS found that only 200 contained an absolute no-strike and nolockout clause. ${ }^{36}$ The building trades unions often retain the right to strike during the term of a contract on selected working rules, such as those governing referral and hiring.

An examination of the trend coefficients in the other strike categories provides support for the belief that the overall trend is not primarily the result of a growing labor force. In the economic-stoppages category, for example, both $W S$ and $W S / M D W$ have negative trend coefficients (though only the latter is significantly different from zero). While the frequency of economic stoppages has tended to decline, those that occur have tended to be more serious as the trend coefficients for $M D I$ and $M D I / W S$ indicate.

The major source of the increasing frequency of construction strikes appears to stem from the strong trend in jurisdictional stoppages, which have increased both in absolute (WS) and relative (WS/MDW) terms. The trend coefficient for jurisdictional disputes indicates that the number of such stoppages increased by 10 a year (ceteris paribus). In contrast to economic stoppages, however, jurisdictional strikes have tended to become less severe; the coefficients for $M D I, M D I / M D W$, and $M D I / W S$ are all significantly negative.

In the category covering strikes over working conditions, the trend variable accounts for very little of the variance. For union-organizing strikes, however, the trend has been to larger, and presumably more serious, confrontations, while their relative frequency has declined.

36U.S. Department of Labor, Bureau of Labor Statistics, Characteristics of Construction Agreements, 1972-1973, Bulletin 1819 (Washington, D.C.: G.P.O., 1974), p. 51 . 
Thus, the overall increase in construction strike frequency may be partly the result of a growing labor force, but appears to be mainly the result of a larger number of jurisdictional strikes. The increasing trend in measures incorporating mandays idle is, by contrast, the result of the increasing seriousness of economic and union-organizing strikes.

Unemployment in Construction. The number of work stoppages in construction does not appear to respond to the unemployment rate in the industry. It is the time lost due to strikes that responds to cyclical changes in the labor market. In all but one category, the time-lost measures ( $M D I, M D I / M D W$, and $M D I /$ $W S$ ) have negative and significant coefficients. A slack labor market does not seem to reduce the frequency of strikes over wages, working conditions, and jurisdictional issues. It does, however, reduce the volume, size, and duration of such disputes. In other words, unemployment does not reduce the union's ability or willingness to initiate a strike, but it may affect its ability to involve a large number of workers for a long period of time.

As unemployment increases in the industry, the arena of industrial conflict appears to shift to union organizing and security. The coefficients for $W S / M D W$, $M D I$, and $M D I / M D W$ are all significantly positive in the union-organizing category. Unemployment apparently increases the resistance of construction employers to union-organizing efforts. ${ }^{37}$

\footnotetext{
3iGustman and Segal have noted the tendency of construction unions to bargain on a multicraft basis when unemployment is high and to bargain independently and to engage in "leap frogging" when unemployment is low. See Alan L. Gustman and Martin Segal, "The Skilled-Unskilled Wage Differential in Construction," Industrial and Labor Relations Re-
}

Possibly it encourages contractors to operate in both unionized and nonunionized segments of the industry, i.e., to be "clouble-breasted." Slack markets may induce some contractors to work under a "merit" or open shop. The building trades maly then try to force such employers to come under the union umbrella. The result is a higher level of strike activity. When unemployment is low, however, employer resistance to union organizing decreases. In a tight labor market the union becomes an assured source of workers. Union-organi\%ing strikes thus clecrease.

The business cycle, then, has a strong impact on the composition of construction strike activity. A downturn in the cycle reduces particularly time lost as a result of economic and working-conditions strikes but increases the strike frequency and idleness resulting from union-organizing attempts.

Wage Controls. The impact of wage controls depends critically on the category of strike considered. Controls clearly tend to reduce conflict arising from economic disputes. The coefficients for all economic strike measures are negative and significant at the .05 level. For example, there tend to be almost 80 fewer economic strikes in a year in which controls are in effect than one would otherwise expect. This is almost a 25 percent reduction in the average postwar level of economic strikes. There is an even larger relative impact on $M D I$ and $M D I / M D W$. In Hicksian terms, the pre-

view, Vol, 27, No. 2 (January 1974), pp. 264-67; see also Mills, Industrial Relations and Manpower in Construction, p. 34. 'The unions' attempts to coordinate bargaining through the creation of multicraft structures when markets are slack may be resisted by employers and thus lead to an increase in union-organizing and security strikes. 
dominant effects of controls on economic disputes is to shift the union's resistance curve leftward.

On the other hand, wage controls have no significant impact on union organizing and jurisdictional strikes. Obviously, these sources of potential discord are not the immediate concern of administrators of a wage-control policy. Government intervention has reduced conflict over wages, but there has been no apparent spillover effect to these other categories. Moreover, wage controls are associated with a significant increase in the frequency of strikes over working conditions. Apparently, construction unions, unable to direct collective pressure on wages during a period of controls, redirect their energies in the broad area of working conditions. Historically, wage controllers have not attempted to restrain union pressures on noneconomic issues during a period of controls. In the construction industry, years in which wage controls are in effect have an average of 20 additional strikes over working conditions. Since such strikes constitute only 10 percent or so of the average total in the industry, this effect is not very substantial in the aggregate. Indeed, wage controls seem to have had no impact on the frequency of total construction disputes but seem to have reduced the volume and scale of total stoppages.

Another method we used to assess the relation between our independent variables and the composition of construction strike activity was to take a direct measure of strike composition as a dependent variable. For example, in one test the percentage of total yearly strikes that were economic in nature $(E C O N / T O T)$ was regressed on trend $(T)$, the unemployment rate in construction $(U)$, and a wage control dummy
$(J)$. The following result was obtained ( $t$-values are in parentheses):

(2)

$$
\begin{aligned}
& .5889-.0090 T-.0052 U-.0787 J \\
& \begin{array}{lll}
(11.41) \quad(4.928) \quad(1.306)
\end{array} \\
& \mathrm{R}^{2}=.681 \quad \text { D.W. }=1.3132
\end{aligned}
$$$$
E C O N / T O T=
$$

For the entire postwar period, economic stoppages constitute 42 percent of total stoppages in the industry. The regression results indicate the following: (l) there is a definite downward trend in the proportion of strikes arising over economic matters, (2) there is no relation between the state of the construction labor market and the proportion of economic strikes, and (3) wage controls definitely are associated with a lower proportion of economic stoppages in the industry. These results are fully consistent with the results displayed in Table 2, which show, for example, that the unemployment rate does not affect the frequency of strikes in any category but does decrease the time lost for all but union-organizing strikes. Experiments with other dependent variables that might serve as direct measures of strike composition also served to verify the results in Table $2 .^{38}$

\section{Summary and Conclusions}

Our principal results can be summarized as follows:

(1.) Strikes in the construction industry became an increasingly serious problem in post World War II industrial relations. Although other studies have shown a general declining trend in U.S. strike activity, strikes in construction have, by most measures, tended to increase.

(2.) The increasing trend is partly the result of the increasing severity of eco-

3 s These results are available from the authors on request. 
nomic and union-organizing strikes and partly the result of the industry's inability to solve the problem of jurisdictional disputes.

(3.) The state of the construction labor market has a pronounced effect on the composition of strike activity. Time lost as a result of strikes over economic issues and working conditions decreases in a slack market, but conflict in the area of union organizing and security increases.

(4.) Finally, wage controls have significantly dampened discord on economic issues, but the number of strikes over working conditions has increased cluring periods of controls. Federal intervention seems to have had, on net, a minor effect on the frequency of labor-management disputes in the industry and a negative effect on the time lost due to these disputes.

Several knowledgeable observers of the industry believe that the craft boards that operated under CISC served to reduce the level of strike activity resulting from wage disputes. As Dunlop commented, while chairman of CISC, "The first thing this industry needs across the board is dispute settling machinery on a national level in all branches. ... I would like to see our craft boards or some combination of them evolve in the period ahead into effective national machinery to resolve disputes over the terms of collective bargaining agreements." 39 It is problematical, however, whether such boards, without the ultimate threat of sanctions available through CISC, can truly serve as an effective disputesettlement mechanism. Continued experimentation with the use of craft boards may be a worthwhile endeavor,

39Construction Labor Report, No. 843 (November 17,1971 ), p. C-3. but our results do not lead to the conclusion that increased federal intervention in the industry's collective bargaining leads unambiguously to reduced levels of conflict.

Problems over union organizing and security will continue to mount as long as the struggle between the open shop movement and the building trades continues. The Associated General Contractors reported in 1974 that more than half of its 3,000 member companies did better than 50 percent of their work with open shops. ${ }^{40}$ There has been an increasing level of violence, as well as an increasing number of strikes, reported in open shop struggles. ${ }^{41}$ We have no ready solution for this problem. Nevertheless, our results suggest that strike activity arising from union organizing can be significantly reduced by maintaining full employment in the industry. Government policies to dampen severe demand fluctuations endemic in the industry would serve the cause of industrial peace and would certainly be a remedy acceptable to all parties.

Jurisdictional disputes have proven a most intractable problem for the industry. Our results show that as the frequency of jurisdictional strikes increased over the post World War II period, their severity declined. These disputes have been a thorn in the side of the industry, but are not particularly costly compared to other sources of conflict. Clearly, part of the explanation for the trend in the frequency of jurisdictional stoppages was the growing ineffectiveness of the National Joint Board. In 1973 the industry succeeded in creating a new

${ }^{40}$ Construction Labor Report, No. 968 (May 1, 1974), p. A.8.

41 Ibid., and Construction Labor Report, No. 976 (June 26, 1974), p. A-2. 
mechanism for the settlement of jurisdictional disputes. "' Hopefully the new procedure, which corrects many of the deficiencies of the old Joint Board, will prove an effective means of reducing strikes over jurisdiction.

Many observers, including Dunlop, have recommended regional or "wide area" bargaining in the construction industry. We can only speculate on the possible impact of more centralized bargaining on strike activity. If the consolidation of bargaining units would reduce the number of contracts negotiated in the industry, then clearly the (legal) opportunity to strike over wages and working conditions would also be reduced. But the propensity to strike, given the opportunity provided by contract expiration, might increase. Furthermore, it is almost certain that consolidated bargaining would mean strikes of larger size and breadth. Moreover, the attempt to establish wide-area units would probably be accompanied by strikes in the "union-organizing and security" category. Wide-area bargaining might have many advantages for the construction industry, but we are skeptical that it would serve to reduce the strike problem. ${ }^{43}$

42Construction Labor Report, No. 922 (June 6, 1973), pp. E-1 to E-8.

4.In September 1975, after this paper was written, the Ford administration introduced a bill, drafted by Secretary of Labor Dumlop, that would restructure collective bargaining in construction by giving national craft unions sole authority to approve contracts negotiated at the local level. Furthermore, the bill would create a new labor-management committee that could defer strikes for up to 30 days past contract expiration. Under the bill, the committee "may promote and assist in the formation of national craft or branch boards... for the purpose of attempting to seek resolution of local labor disputes." The text of the bill is found in Construction Labor Report, No. 1038 (Sep. tember 10, 1975), pp. E-l to E-3. This bill was eventually coupled with a controversial commonsitus picketing bill, however, and although the joint measure passed both houses of Congress, it was vetoed by President Ford in December 1975 . 